Article

\title{
Phosphorus in Spring Barley and Italian Rye-Grass Biomass as an Effect of Inter-Species Interactions under Water Deficit
}

\author{
Marta K. Kostrzewska *, Magdalena Jastrzębska *(D), Kinga Treder ${ }^{(D)}$ and Maria Wanic \\ Department of Agroecosystems, Faculty of Environmental Management and Agriculture, \\ University of Warmia and Mazury in Olsztyn, Plac Łódzki 3, 10-718 Olsztyn, Poland; \\ kinga.treder@uwm.edu.pl (K.T.); maria.wanic@uwm.edu.pl (M.W.) \\ * Correspondence: marta.kostrzewska@uwm.edu.pl (M.K.K.); jama@uwm.edu.pl (M.J.)
}

Received: 30 June 2020; Accepted: 3 August 2020; Published: 5 August 2020

\begin{abstract}
With global warming, the problem of soil water deficit is growing in Central Europe, including Poland, and the use of catch crops is recommended to mitigate climate changes. This study aimed to determine the influence of water deficit on phosphorus $(\mathrm{P})$ content and accumulation in the above-ground biomass of spring barley and Italian rye-grass growing separately and in the mixture, and on the inter-species interactions between these crops. The study was based on a pot experiment established in accordance with the additive design. The experimental factors were as follows: A. water supply of the plants: an optimal dose and a dose reduced by $50 \%$ in relation to the optimal dose, and B. the sowing type: barley sown as a single species, rye-grass sown as a single species, and barley with rye-grass catch crop. Based on the $P$ accumulation in plant biomass, the relative yield of barley and rye-grass, the total relative yield, and the competitive equilibrium index were determined. Water deficit had no effect on the $\mathrm{P}$ content in the plants, but it reduced the $\mathrm{P}$ accumulation in barley stems, leaves and spikes, as well as in rye-grass stems and leaves, from the emergence to the end of plants' growing period, both when the plants were sown as a single species and as a mixture. Barley was a stronger competitor than rye-grass. Inter-species competition occurred at the stem elongation and heading of barley. The intensification of inter-species competition for $\mathrm{P}$ under water deficit conditions should be taken into account when recommending the undersowing of barley with rye-grass for sustainable agriculture.
\end{abstract}

Keywords: Hordeum vulgare; Lolium multiflorum; phosphorus; water stress; competition indices; plant development stages

\section{Introduction}

Stress in organisms can be induced by either abiotic or biotic factors [1]. In agro-ecosystems, of all the abiotic factors, drought is the main determinant that limits the development of plants and, consequently, their yielding [2]. Central Europe, including Poland, is located in a temperate climate [3], where the relevance of drought is often underestimated [4]. However, in recent years, with global climate change, the problem of drought has become increasingly serious in the region [4]. Rising atmospheric temperatures have resulted in increasing evapotranspiration rates [4], and seasonal and monthly distributions of precipitation have also been changing [5]. Drying trends were observed for spring and less pronounced for summer, i.e., for a large part of the vegetation period [5]. In general, drought reduces the uptake of minerals and their transport from the roots to the above-ground parts, which affects the rate of plant physiological processes [6]. Tolerance to water stress is a very important feature of plants during drought. Knowledge of species' sensitivity and response to water 
deficit can be helpful while selecting plants for cultivation, particularly in regions at risk of drought. Numerous studies indicate that resistance to stress is a genotypic trait [7-10].

Catch crops undersown in small grains (main crop) is a form of mixed cropping which offers numerous environmental benefits [11,12], and is considered as a sustainable agricultural practice [12,13]. Catch crop residues left in the field are a significant source of nutrient-rich organic matter [14]. After harvesting the main crop, they serve as ground covers and reduce nitrogen and phosphorus (P) leaching from the soil, as well as direct and indirect greenhouse gas emissions [15-19]. For the latter reason, the cultivation of catch crops is claimed to make an important contribution to climate change mitigation $[20,21]$. However, underplanted catch crops may compete for nutrients with the main crop [22,23], especially in unfavorable conditions such as water deficit [24]. Italian ryegrass (Lolium multiflorum) is one of the most popular catch crops, often undersown in spring barley (Hordeum vulgare) $[25,26]$.

Hordeum vulgare is cultivated in many countries worldwide, with the grains intended mainly for animal feed purposes [27]. It is usually cultivated as the main crop. It is ranked fourth, following wheat, rice and maize, in terms of the area under cultivation [28]. Similarly to other cereals, it is also included in mixtures with leguminous plants [29-32], and is used as a protective plant for underplanted catch crops [25,33-35]. The species is distinguished by natural tolerance to drought [36]. This tolerance is determined by early flowering, which ensures optimal pollination, seed development and ripening in an optimal time period. In cereals, the consequences of water deficiency are determined by both the plant's development stage during which the stress occurs [37], and the frequency of drought occurrence during plant development [38].

Lolium multiflorum is a fast-growing annual or perennial grass originating from Europe [39]. L. multiflorum, similarly to L. perenne, is a valuable fodder plant cultivated in many regions of the world, in both dry and rainy areas [33,40-42]. L. multiflorum is cultivated as the main crop, but it can also be cultivated as an underplanted catch crop, similarly to other grasses, papilionaceous plants and their mixtures $[15,43,44]$.

Phosphorus $(\mathrm{P})$ is the second macronutrient after nitrogen, whose deficiency most frequently inhibits plant growth [45]. Poor water availability reduces the uptake of macronutrients from the soil [46,47], and may also affect their content in plants [48-51]. The more severe the drought, the more adverse the effect on the component ratio in the plant [52]. The literature offers many articles on the competition between the cultivated plants, particularly cereals and papilionaceous plants, for habitat resources [53-57]. However, no models have ever been developed to fully explain how plants compete for nutrients under water deficit conditions. Various indicators are used to assess this interaction, e.g., relative yield, relative competitive capacity [58], which are based not only on plant biomass [59], but also on the accumulation of macroelements [23,60]. Relatively more is known about nitrogen accumulation, while there are few studies on phosphorus $[61,62]$. This study may complement this information.

The study aimed to determine the influence of water deficit on P content and accumulation in the above-ground biomass of spring barley and Italian rye-grass growing separately and in the mixture (rye-grass undersown in barley), and on the inter-species interactions between these crops at different plant development stages.

\section{Materials and Methods}

\subsection{Experimental Design}

The study was based on a pot experiment conducted at a greenhouse laboratory of the Faculty of Biology and Biotechnology, University of Warmia and Mazury. The study was carried out on spring barley (Rastik cultivar) and Italian rye-grass (Gaza cultivar).

The experimental factors were as follows:

1. water supply of the plants: optimal (OW), and reduced by $50 \%$ in relation to the optimal one (LW), 
2. sowing type: barley grown as a single species (BP), rye-grass grown as a single species (RP), barley in a mixture with rye-grass (BM), and rye-grass in a mixture with barley (RM).

An optimal dose of water was determined in a trial experiment, in which plants' irrigation requirements were established based on water loss estimated by daily measurements of pot weight. At the beginning of the trial experiment, the pots with plants were well irrigated, and the soil moisture content was maintained daily by re-watering with the water lost in the previous $24 \mathrm{~h}$. Daily amounts of water supplied to the pots with barley, rye-grass and barley-rye-grass mixture were recorded during the successive growth stages. After finishing the trial experiment, based on the recorded data of water amounts used for daily irrigation, the pattern of plant watering with a higher dose for the proper experiment was established. A higher daily dose of water, common for the three types of sowing, was calculated as an average of barley, rye-grass, and barley-rye-grass mixture requirements at a given stage of plant growth. This dose was dynamic according to the plant development (changeable during vegetation), and it was slightly verified during each growing season. The reduced dose was always equal to one-half of the higher one. At the beginning of each experimental series of the experiment (sowing), the soil moisture was about 20\% (measured by time domain reflectometry (TDR) method).

The plants were cultivated on proper brown soil formed from slightly loamy silty sand. The soil had a slightly acidic reaction ( $\mathrm{pH}$ in $1 \mathrm{M} \mathrm{KCl} \mathrm{5.6-6.1),} \mathrm{average} \mathrm{phosphorus} \mathrm{(51-61} \mathrm{mg} \mathrm{kg-1),}$ potassium (98-117 mg kg-1) and magnesium (33-42 $\mathrm{mg} \mathrm{kg}^{-1}$ ) content, and an organic carbon content of 7.1-11.1 $\mathrm{g} \mathrm{kg}^{-1}$. Each pot, a week before sowing, was filled with $8 \mathrm{~kg}$ soil material previously mixed with mineral fertilizers, in a dose of pure component $\left(\mathrm{g} \mathrm{pot}^{-1}\right)$ : $\mathrm{N}-0.5$ (urea), $\mathrm{P}-0.2$ (monopotassium phosphate), $\mathrm{K}-0.45$ (potassium sulphate).

Plant kernels were sown into Kick-Brauckmann pots (diameter of $22 \mathrm{~cm}$, depth of $28 \mathrm{~cm}$ ). When preparing the mixture, the additive pattern was applied, as it assesses the species' interactions at early development stages better than the substitution pattern $[63,64]$. When single-species sowing was applied, 18 spring barley kernels or 18 Italian rye-grass kernels were sown, while for the mixed-species sowing, 18 spring barley kernels and 18 Italian rye-grass kernels were sown (pure sowing stand). The kernels were distributed using templates at an equal distance from each other over the soil surface, and placed at a depth of $3 \mathrm{~cm}$.

From the kernel sowing to plant harvesting, the temperature at the laboratory was maintained at $20-22{ }^{\circ} \mathrm{C}$. The exception was a 9-day period during the full plant emergence when the temperature was lowered to $6-8^{\circ} \mathrm{C}$ to pass the vernalization process.

Three one-year cycles of the experiment were conducted. Each year (cycle), an experiment was set up according to completely randomized design in four replications, and comprised 120 pots: two levels of plant water supply $x$ three levels of sowing type (two species sown separately and in a mixture) $x$ five testing dates $x$ four replications.

\subsection{Plant Sampling and Analysis}

The phosphorus content in the above-ground biomass of the plants was assayed in five developmental periods, determined by the developmental rhythm of barley sown as a single species and supplied with an optimum water dose. These included (according to $\mathrm{BBCH}$ scale): leaf development (10-13), tillering (22-25), stem elongation (33-37), heading (52-55), and ripening (87-91). When barley reached the appropriate stage, the plants were removed from pots (intended for a particular stage), and the shoots were separated from the roots. The material subjected to testing included the above-ground parts of barley and rye-grass plants. The plants were dried in the air and then weighed. For barley, beginning from the stem elongation stage, the shoots were separated into stems and leaves, and from the heading stage, into the spikes as well. For rye-grass, the shoots were separated into the stems and leaves, beginning from the barley stem elongation stage.

The phosphorus content was assayed by the spectrophotometric method (PN-ISO 6491:2000) [65], at the Chemical and Agricultural Research Laboratory in Olsztyn. 


\subsection{Calculations}

The phosphorus accumulation was calculated by multiplying the content of this element in individual parts of the plants by the weight of these organs.

Based on the phosphorus accumulation in the total above-ground biomass of the plants, the relative yield (RY) (Equation (1)) and the total relative yield (RYT) (Equation (2)) were determined [66]:

$$
\begin{gathered}
R Y_{B}=Y_{B M} / Y_{B P} \text { and } R Y_{R}=Y_{R M} / Y_{R P} \\
R Y T=R Y_{B}+R Y_{R}
\end{gathered}
$$

The relative competitive capacity for phosphorus in mixed seedings was expressed as the competitive equilibrium index $(\mathrm{Cb})$ (Equation (3)) [67]:

$$
\mathrm{Cb}=\ln \left[\left(\mathrm{Y}_{\mathrm{BM}} / \mathrm{Y}_{\mathrm{RM}}\right) /\left(\mathrm{Y}_{\mathrm{BP}} / \mathrm{Y}_{\mathrm{RP}}\right)\right]
$$

where: $\mathrm{RY}_{\mathrm{B}}$-relative barley yield, $\mathrm{Y}_{\mathrm{BM}}$-barley in mixture yield, $\mathrm{Y}_{\mathrm{BP}}$-barley yield for single-species sowing, $R Y_{R}$-relative rye-grass yield, $Y_{R M}$-rye-grass in mixture yield, $Y_{R P}$-rye-grass yield for single-species sowing, $\ln -$ natural logarithm.

In the additive pattern, $\mathrm{RY}<1$ indicates competition, $\mathrm{RY}>1$ indicates positive interactions, and $\mathrm{RY}=1$ no interactions. If RYT $>1$, this indicates partial complementarity in resource acquisition by the mixture components, positive interactions between species, or incomplete resource acquisition by species in single-species seedings, while if $\mathrm{RYT}=2$, there are no competitive interactions between species in the mixture, as the resource acquisition by each species in the mixture is the same as in the single-species sowing [60].

The competitive equilibrium index $\mathrm{Cb}$ indicates which of the species is more competitive. The experiment calculated $\mathrm{Cb}$ for barley in relation to Italian rye-grass. If the species are equal competitors, then $\mathrm{Cb}=0$, if barley is a better competitor than rye-grass, then $\mathrm{Cb}>0$, and if rye-grass is a better competitor than barley, then $\mathrm{Cb}<0$.

\subsection{Statistical Analysis}

The results were subjected to the analysis of variance (ANOVA). The statistics were calculated separately for each growth stage and for individual plant parts. Homogeneous groups were identified by Duncan's test at $p<0.05$. Using correlation coefficients, the relationship between the phosphorus accumulation and its content in the organs of plants and their above-ground biomass (the leaves, stems and spikes) was presented. The correlation coefficients were calculated separately for barley and rye-grass, based on the results from all objects (irrespective of the water supply of the plants). It was also checked as to whether the RY and RYT values differ significantly from the unity, and the $\mathrm{Cb}$ values from zero, using the t-Student test [60]. Statistical analyses were carried out using the STATISTICA software (data analysis software system), version 12, StatSoft [68].

The results in the tables are means for the three cycles (years) of the experiment.

\section{Results}

\subsection{Phosphorus Content and Accumulation}

\subsubsection{Spring Barley}

The water supply of the plants and the type of sowing had no significant effect on the P content in the above-ground parts of barley throughout the growing period (Table S1).

Water deficit (LW) and the vicinity of rye-grass (BM) reduced $\mathrm{P}$ accumulation in the total barley above-ground biomass and individual organs (Table 1). Only at the ripening stage was the $P$ accumulation in barley leaves not affected by the type of sowing. Throughout the cereal vegetation, 
most $\mathrm{P}$ in the above-ground biomass and the organs was accumulated by the plants BP-OW. Water deficit $(\mathrm{LW})$ reduced the $\mathrm{P}$ accumulation more than the presence of rye-grass $(\mathrm{BM})$, and the interaction of these factors (BM-LW) resulted in a further reduction in $\mathrm{P}$ accumulation.

Table 1. Phosphorus accumulation by barley $\left(\mathrm{mg} \mathrm{pot}^{-1}\right)$.

\begin{tabular}{|c|c|c|c|c|c|c|c|c|c|}
\hline \multirow{2}{*}{$\begin{array}{l}\text { Growth Stage } \\
\text { of Barley }\end{array}$} & \multirow{2}{*}{$\begin{array}{c}\text { Plant } \\
\text { Part }\end{array}$} & \multicolumn{2}{|c|}{ Water Supply } & \multicolumn{2}{|c|}{ Sowing Type } & \multicolumn{4}{|c|}{ Water Supply x Sowing Type } \\
\hline & & OW & LW & BP & BM & BP-OW & BM-OW & BP-LW & BM-LW \\
\hline $\begin{array}{c}\text { Leaf } \\
\text { development }\end{array}$ & shoots & $5.57^{\mathrm{a}}$ & $4.10^{\mathrm{b}}$ & $5.22^{\mathrm{a}}$ & $4.44^{\mathrm{b}}$ & $5.98^{a}$ & $5.15^{b}$ & $4.46^{\mathrm{c}}$ & $3.74^{\mathrm{d}}$ \\
\hline Tillering & shoots & $22.47^{a}$ & $10.53^{b}$ & $17.13^{\mathrm{a}}$ & $15.87^{\mathrm{b}}$ & $23.13^{a}$ & $21.81^{\mathrm{b}}$ & $11.13^{c}$ & $9.92^{c}$ \\
\hline \multirow{3}{*}{$\begin{array}{c}\text { Stem } \\
\text { elongation }\end{array}$} & shoots & $57.01^{\mathrm{a}}$ & $22.77^{\mathrm{b}}$ & $44.15^{\mathrm{a}}$ & $35.64^{b}$ & $62.42^{\mathrm{a}}$ & $51.60^{\mathrm{b}}$ & $25.88^{c}$ & $19.67^{\mathrm{d}}$ \\
\hline & leaves & $20.87^{\mathrm{a}}$ & $10.02^{b}$ & $17.41^{\mathrm{a}}$ & $13.48^{\mathrm{b}}$ & $23.51^{\mathrm{a}}$ & $18.23^{b}$ & $11.32^{\mathrm{c}}$ & $8.72^{\mathrm{d}}$ \\
\hline & stems & $36.14^{\mathrm{a}}$ & $12.76^{\mathrm{b}}$ & $26.74^{\mathrm{a}}$ & $22.16^{\mathrm{b}}$ & $38.91^{\mathrm{a}}$ & $33.37^{b}$ & $14.56^{\mathrm{c}}$ & $10.95^{\mathrm{d}}$ \\
\hline \multirow{4}{*}{ Heading } & shoots & $68.28^{a}$ & $29.66^{b}$ & $54.37^{\mathrm{a}}$ & $43.57^{b}$ & $74.75^{\mathrm{a}}$ & $61.82^{b}$ & $33.99^{c}$ & $25.33^{d}$ \\
\hline & leaves & $18.37^{\mathrm{a}}$ & $11.57^{\mathrm{b}}$ & $17.47^{\mathrm{a}}$ & $12.47^{b}$ & $22.52^{\mathrm{a}}$ & $14.22^{b}$ & $12.43^{c}$ & $10.72^{\mathrm{d}}$ \\
\hline & stems & $35.74^{a}$ & $13.99^{b}$ & $26.61^{a}$ & $23.13^{b}$ & $36.57^{a}$ & $34.92^{b}$ & $16.65^{c}$ & $11.34^{\mathrm{d}}$ \\
\hline & spikes & $14.17^{\mathrm{a}}$ & $4.09^{b}$ & $10.29^{a}$ & $7.98^{b}$ & $15.66^{\mathrm{a}}$ & $12.69^{b}$ & $4.91^{\mathrm{c}}$ & $3.28^{\mathrm{d}}$ \\
\hline \multirow{4}{*}{ Ripening } & shoots & $48.88^{a}$ & $36.58^{b}$ & $46.21^{a}$ & $39.25^{b}$ & $51.85^{\mathrm{a}}$ & $45.91^{b}$ & $40.58^{c}$ & $32.59^{d}$ \\
\hline & leaves & $10.46^{\mathrm{a}}$ & $9.42^{b}$ & $10.04^{\mathrm{a}}$ & $9.84^{\mathrm{a}}$ & $10.40^{\mathrm{ab}}$ & $10.51^{a}$ & $9.68^{b c}$ & $9.17^{c}$ \\
\hline & stems & $20.15^{a}$ & $17.43^{b}$ & $19.86^{\mathrm{a}}$ & $17.71^{b}$ & $19.44^{\mathrm{a}}$ & $20.85^{a}$ & $20.28^{a}$ & $14.57^{b}$ \\
\hline & spikes & $18.28^{a}$ & $9.74^{b}$ & $16.31^{a}$ & $11.70^{\mathrm{b}}$ & $22.00^{\mathrm{a}}$ & $14.55^{b}$ & $10.62^{c}$ & $8.86^{\mathrm{d}}$ \\
\hline
\end{tabular}

OW—optimal water supply, LW—water supply reduced by 50\%; BP—barley as a single species, BM-barley in a mixture with rye-grass; a, b, c, d-homogeneous groups (values followed by the same letters, for each phase and for each part of the plant, within experimental factors and their interactions are not significantly different at $p<0.05$ ).

The amount of accumulated P was strongly correlated with the amount of barley above-ground biomass (Table 2). Moreover, a positive correlation was demonstrated between the $\mathrm{P}$ accumulation and $\mathrm{P}$ content in the vegetative organs of barley during tillering and stem elongation, and between the $\mathrm{P}$ accumulation and $\mathrm{P}$ content in the barley stems at the heading and ripening stages.

Table 2. Coefficients of correlation (r) between phosphorus accumulation and phosphorus (P) content and the above-ground biomass of plants.

\begin{tabular}{cccccc}
\hline \multirow{2}{*}{ Growth Stage of Barley } & \multirow{2}{*}{ Plant Part } & \multicolumn{2}{c}{ Barley } & \multicolumn{2}{c}{ Rye-Grass } \\
\cline { 3 - 6 } & & P Content & Biomass & P Content & Biomass \\
\hline Leaf development & shoots & 0.041 & $0.977^{*}$ & $0.291^{*}$ & $0.960^{*}$ \\
\hline Tillering & shoots & $0.618^{*}$ & $0.944^{*}$ & $0.584^{*}$ & $0.993^{*}$ \\
\hline \multirow{2}{*}{ Stem elongation } & leaves & $0.481^{*}$ & $0.946^{*}$ & $0.293^{*}$ & $0.946^{*}$ \\
& stems & $0.602^{*}$ & $0.968^{*}$ & 0.229 & $0.990^{*}$ \\
\hline \multirow{2}{*}{ Heading } & leaves & 0.116 & $0.934^{*}$ & -0.024 & $0.963^{*}$ \\
& stems & $0.557^{*}$ & $0.905^{*}$ & -0.229 & $0.980^{*}$ \\
& spikes & 0.274 & $0.942^{*}$ & - & - \\
\hline \multirow{2}{*}{ Ripening } & leaves & 0.125 & $0.769^{*}$ & 0.110 & $0.850^{*}$ \\
& stems & $0.493^{*}$ & $0.880^{*}$ & $-0.591 *$ & $0.985^{*}$ \\
& spikes & -0.035 & $0.994^{*}$ & - & - \\
\hline
\end{tabular}

${ }^{*} \mathrm{r}$ significant at $p<0.05$.

\subsubsection{Italian Rye-Grass}

The $\mathrm{P}$ content in the vegetative organs of rye-grass throughout the growing period was not affected by the water supply of the plants or the type of sowing (Table S2). 
Both water deficit (LW) and the vicinity of barley (RM) reduced the amount of accumulated $P$ in the rye-grass above-ground biomass (Table 3). The strength of the effects of the interaction between water deficiency and barley's competition (RM-LW) on this feature varied at different development stages of the cereal. At the barley leaf development stage, a higher P accumulation was noted in rye-grass RP-OW than RM-OW, in the absence of differences between RP-LW and RM-LW plants. During barley tillering, the reducing effect of water deficit was still noted, but under these conditions, the competitive effect of barley against rye-grass was also observed. From the stem elongation stage until the end of vegetation, the vicinity of barley reduced the $P$ accumulation in rye-grass leaves and stems more than water deficit, and the interaction of stress factors (RM-LW) deepened this reduction.

Table 3. Phosphorus accumulation by rye-grass $\left(\mathrm{mg} \operatorname{pot}^{-1}\right)$.

\begin{tabular}{cccccccccc}
\hline \multirow{2}{*}{$\begin{array}{c}\text { Growth Stage } \\
\text { of Barley }\end{array}$} & $\begin{array}{c}\text { Plant } \\
\text { Part }\end{array}$ & \multicolumn{2}{c}{ Water Supply } & \multicolumn{2}{c}{ Sowing Type } & \multicolumn{2}{c}{ Water Supply x Sowing Type } \\
\cline { 2 - 9 } & OW & LW & RP & RM & RP-OW & RM-OW & RP- LW & RM-LW \\
\hline $\begin{array}{c}\text { Leaf } \\
\text { development }\end{array}$ & shoots & $0.94^{\mathrm{a}}$ & $0.65^{\mathrm{b}}$ & $0.85^{\mathrm{a}}$ & $0.74^{\mathrm{b}}$ & $1.06^{\mathrm{a}}$ & $0.82^{\mathrm{b}}$ & $0.64^{\mathrm{c}}$ & $0.66^{\mathrm{c}}$ \\
\hline Tillering & shoots & $9.67^{\mathrm{a}}$ & $3.34^{\mathrm{b}}$ & $9.54^{\mathrm{a}}$ & $3.47^{\mathrm{b}}$ & $14.00^{\mathrm{a}}$ & $5.33^{\mathrm{b}}$ & $5.07^{\mathrm{b}}$ & $1.62^{\mathrm{c}}$ \\
\hline \multirow{2}{*}{ Stem } & shoots & $28.34^{\mathrm{a}}$ & $14.10^{\mathrm{b}}$ & $32.71^{\mathrm{a}}$ & $9.73^{\mathrm{b}}$ & $43.03^{\mathrm{a}}$ & $13.64^{\mathrm{c}}$ & $22.39^{\mathrm{b}}$ & $5.81^{\mathrm{d}}$ \\
elongation & leaves & $14.02^{\mathrm{a}}$ & $9.02^{\mathrm{b}}$ & $16.50^{\mathrm{a}}$ & $6.54^{\mathrm{b}}$ & $18.80^{\mathrm{a}}$ & $9.23^{\mathrm{c}}$ & $14.20^{\mathrm{b}}$ & $3.85^{\mathrm{d}}$ \\
& stems & $14.32^{\mathrm{a}}$ & $5.08^{\mathrm{b}}$ & $16.21^{\mathrm{a}}$ & $3.19^{\mathrm{b}}$ & $24.23^{\mathrm{a}}$ & $4.41^{\mathrm{c}}$ & $8.19^{\mathrm{b}}$ & $1.96^{\mathrm{d}}$ \\
\hline \multirow{3}{*}{ Heading } & shoots & $57.69^{\mathrm{a}}$ & $29.82^{\mathrm{b}}$ & $65.56^{\mathrm{a}}$ & $21.95^{\mathrm{b}}$ & $85.22^{\mathrm{a}}$ & $30.16^{\mathrm{c}}$ & $45.90^{\mathrm{b}}$ & $13.74^{\mathrm{d}}$ \\
& leaves & $36.26^{\mathrm{a}}$ & $18.98^{\mathrm{b}}$ & $40.77^{\mathrm{a}}$ & $14.47^{\mathrm{b}}$ & $52.56^{\mathrm{a}}$ & $19.96^{\mathrm{c}}$ & $28.98^{\mathrm{b}}$ & $8.99^{\mathrm{d}}$ \\
& stems & $21.43^{\mathrm{a}}$ & $10.83^{\mathrm{b}}$ & $24.79^{\mathrm{a}}$ & $7.47^{\mathrm{b}}$ & $32.66^{\mathrm{a}}$ & $10.20^{\mathrm{c}}$ & $16.92^{\mathrm{b}}$ & $4.75^{\mathrm{d}}$ \\
\hline \multirow{2}{*}{ Ripening } & shoots & $63.58^{\mathrm{a}}$ & $35.71^{\mathrm{b}}$ & $70.27^{\mathrm{a}}$ & $29.02^{\mathrm{b}}$ & $89.6^{\mathrm{a}}$ & $37.55^{\mathrm{c}}$ & $50.92^{\mathrm{b}}$ & $20.49^{\mathrm{d}}$ \\
& leaves & $44.71^{\mathrm{a}}$ & $25.71^{\mathrm{b}}$ & $50.20^{\mathrm{a}}$ & $20.22^{\mathrm{b}}$ & $63.64^{\mathrm{a}}$ & $25.78^{\mathrm{c}}$ & $36.76^{\mathrm{b}}$ & $14.66^{\mathrm{d}}$ \\
& stems & $18.82^{\mathrm{a}}$ & $10.00^{\mathrm{b}}$ & $20.07^{\mathrm{a}}$ & $8.75^{\mathrm{b}}$ & $25.98^{\mathrm{a}}$ & $11.66^{\mathrm{c}}$ & $14.16^{\mathrm{b}}$ & $5.83^{\mathrm{d}}$ \\
\hline
\end{tabular}

OW—optimal water supply, LW—-water supply reduced by $50 \%$; RP—rye-grass as a single species, RM-rye-grass in a mixture with barley; a, b, c, d-homogeneous groups (values followed by the same letters, for each phase and for each part of the plant, within experimental factors and their interactions are not significantly different at $p<0.05$ ).

The $\mathrm{P}$ accumulation in the plants was determined by the above-ground biomass of rye-grass (Table 2). Moreover, a positive correlation between the $\mathrm{P}$ accumulation and $\mathrm{P}$ content in rye-grass vegetative organs until the stem elongation stage and a strong negative correlation between the $\mathrm{P}$ accumulation and $\mathrm{P}$ content in rye-grass stems during barley ripening were found.

\subsection{Competition for Phosphorus}

Throughout the growing period, irrespective of the water supply of the plants, there was competition for $P$ between barley and rye-grass $\left(R Y_{B}<1\right.$ and $\left.R Y_{R}<1\right)$ (Table 4$)$. Only during the period of leaf development under water deficit (LW) were no effects of barley on rye-grass noted $\left(R Y_{R}=1.04\right)$. A water deficit increased the competition intensity, especially of rye-grass against barley from the stem elongation stage to the end of barley vegetation $\left(R Y_{B}=0.75-0.80\right)$ and of barley against rye-grass from the tillering stage to the barley heading stage $\left(R Y_{R}=0.26-0.32\right)$. Consequently, during the barley stem elongation and heading stages under water stress conditions, there was full competition between the species (RYT did not differ from 1) (Figure 1). At other development stages, the plants made use of the resource, partially in a complementary manner $(\mathrm{RYT}>1)$. 
Table 4. RY values for barley and rye-grass (based on P accumulation) depending on the water supply of the plants.

\begin{tabular}{ccccc}
\hline \multirow{2}{*}{ Growth Stage of Barley } & \multicolumn{4}{c}{ Water Supply } \\
\cline { 2 - 5 } & \multicolumn{3}{c}{ OW } & \multicolumn{3}{c}{$\mathbf{L W}$} \\
\cline { 2 - 5 } & $\mathbf{R} \mathbf{Y}_{\mathbf{B}}$ & $\mathbf{R} \mathbf{Y}_{\mathbf{R}}$ & $\mathbf{R} \mathbf{Y}_{\mathbf{B}}$ & $\mathbf{R} \mathbf{Y}_{\mathbf{R}}$ \\
\hline Leaf development & $0.86^{\mathrm{bc} *}$ & $0.78^{\mathrm{a} *}$ & $0.84^{\mathrm{ab} *}$ & $1.04^{\mathrm{a}}$ \\
\hline Tillering & $0.94^{\mathrm{a}}$ & $0.38^{\mathrm{bc} *}$ & $0.89^{\mathrm{a} *}$ & $0.32^{\mathrm{bc} *}$ \\
\hline Stem elongation & $0.83^{\mathrm{c} *}$ & $0.32^{\mathrm{c} *}$ & $0.76^{\mathrm{c} *}$ & $0.26^{\mathrm{c} *}$ \\
\hline Heading & $0.83^{\mathrm{c} *}$ & $0.35^{\mathrm{bc} *}$ & $0.75^{\mathrm{c} *}$ & $0.30^{\mathrm{bc} *}$ \\
\hline Ripening & $0.89^{\mathrm{b} *}$ & $0.42^{\mathrm{b} *}$ & $0.80^{\mathrm{bc} *}$ & $0.40^{\mathrm{b} *}$ \\
\hline
\end{tabular}

OW—optimal water supply, LW—water supply reduced by $50 \%$; $R Y_{B}-R Y$ values for barley, $R Y_{R}-R Y$ values for rye-grass; $a, b, c-$ homogeneous groups (values in the column of the table within species values followed by the same letters are not significantly different at $p<0.05) ;{ }^{*} \mathrm{R} Y_{B}, R Y_{R}$, significantly different from $1.0(p=0.05)$.

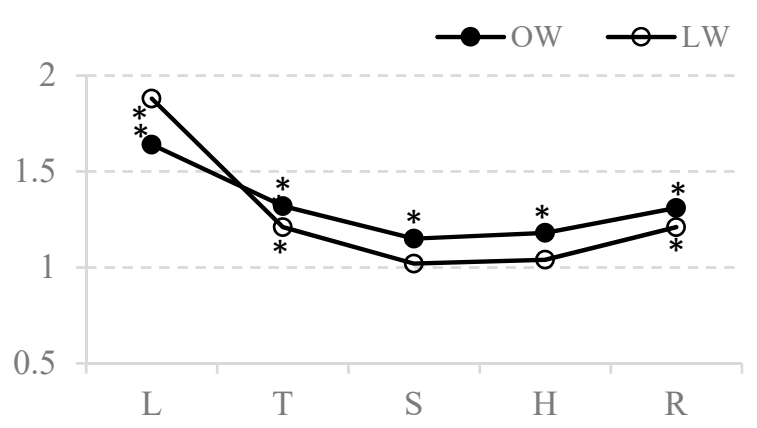

(a)

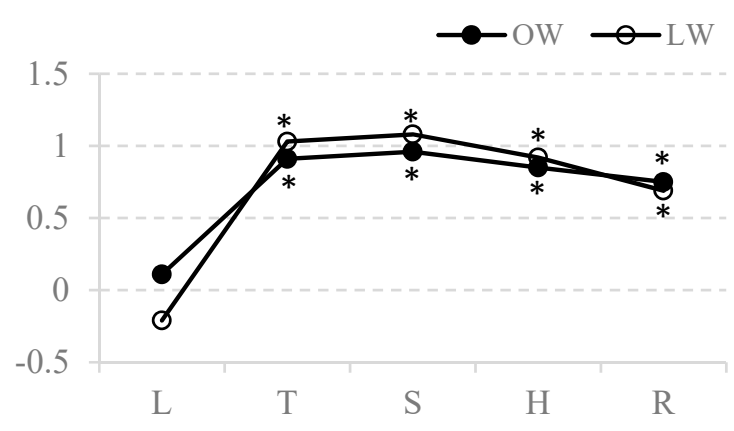

(b)

Figure 1. Changes in the RYT (a) and $\mathrm{Cb}(\mathbf{b})$ values for the mixture of barley and rye-grass catch crop during the growth. OW-optimal water supply, LW-water supply reduced 50\%; growth stage of barley: L-leaf development, T-tillering, S-stem elongation, $\mathrm{H}$-heading, $\mathrm{R}$-ripening; * - RYT significantly different from $1.0(p=0.05)$ and $\mathrm{Cb}$ significantly different from $0.0(p=0.05)$.

Both under conditions of optimal water supply of the plants and water deficit, the competition of rye-grass against barley was most intense during barley stem elongation and heading. On the other hand, the competition of barley against rye-grass from the tillering to heading stages was the most intense during stem elongation. Barley was a stronger competitor than rye-grass (the $\mathrm{Cb}$ index was significantly higher than 0) (Figure 1).

\section{Discussion}

\subsection{Phosphorus Content and Accumulation in Barley}

The current study demonstrated no effects of water deficit on the P content in barley above-ground parts throughout the growing period. The results of other studies conducted to date on the effects of water stress on this feature are inconclusive. Both reports of no change [24] and of a reduction in the $P$ content $[52,69]$ of the barley biomass with an increase in water stress were noted.

The type of sowing had no effect on the P content in barley above-ground biomass in the current study. A convergent result was presented by Jastrzęskka et al. [24], who examined the effect of red clover as a catch crop accompanying spring barley. On the other hand, Wanic and Michalska [31] demonstrated that mixed barley and pea sowing increased the $\mathrm{P}$ content in the cereal above-ground biomass, at the heading and ripening stages.

The reduction in the $\mathrm{P}$ accumulation in barley above-ground biomass due to water deficit and the presence of rye-grass was proven in the current study. To compare, Jastrzębska et al. [24] found 
that mixed spring barley and red clover sowing did not differentiate the amount of $\mathrm{P}$ accumulated in the cereal until the heading stage, and at the heading stage, it significantly reduced the amount in the leaves. The current study demonstrated that $\mathrm{P}$ accumulation was determined by the biomass produced, and only during the initial period of plant development by $\mathrm{P}$ content in the plant. Lower $\mathrm{P}$ accumulation under water deficit conditions indicates a smaller biomass. A reduction in barley biomass under drought conditions was confirmed in studies by other authors [52,70-72].

\subsection{Phosphorus Content and Accumulation in Rye-Grass}

In the current study, the P content in the above-ground stems and leaves of rye-grass was not affected by the water supply of the plants. AbdElgawad et al. [73] also found that drought and high temperatures had no significant effect on the $\mathrm{P}$ and other nutrient concentrations in the above-ground biomass of grasses (Poa pratensis, Lolium perenne) and legumes (Lotus corniculatus, Medicago lupulina). No changes in the $\mathrm{P}$ content in rye-grass growing in the vicinity of spring barley were found in the current study either. On the other hand, Høgh-Jensen and Schjoerring [74] demonstrated that P concentration in the dry matter of Lolium perenne shoots in the single-species sowing was lower than noted when rye-grass was sown in a mixture with Trifolium repens.

There are few studies on the effects of water deficit and competition on P accumulation in the rye-grass biomass. Indirectly, conclusions about it can be drawn based on the biomass, since the $\mathrm{P}$ accumulation throughout the growing period had a positive correlation with the above-ground biomass accumulation. Brink et al. [75] also indicates a strong correlation between P uptake and the dry matter of Lolium multiflorum, while Burkitt et al. [76] explain such a relationship for Lolium perenne. Italian rye-grass is sensitive to water scarcity and primarily responds with poor tillering [77], which can result in lower biomass. The sensitivity of grasses to drought is a feature of the species [78], and even a varietal feature [79], while agronomic and physiological effects of water deficit are determined by the duration of drought [10]. On the other hand, the strength of the effect of a protective (main) crop on the development of catch crop is determined by the protective crop species and the catch crop species. Barley is regarded as a good protective crop for underplanted catch crops [25]. Kuraszkiewicz and Pałys [35] demonstrated that winter rye is a better protective crop than spring barley and oats, and in years with high precipitation, the yields of both fresh and the air-dry above-ground biomass of the catch crop are greater.

\subsection{Relative Yields}

The nutrient accumulation in plant biomass can result from inter-species interactions such as competition, facilitation and complementarity [74]. For example, a study by Rahetlah et al. [59] demonstrated that Italian rye-grass and spring vetch make complementary use of resources, and that such a mixture could be an alternative to a rye-grass single-crop system, particularly in the dry season. Based on the $\mathrm{P}$ accumulation in the plant biomass, expressed as relative yields, it was demonstrated that barley and rye-grass competed for $\mathrm{P}$ during the stem elongation and heading stages under water deficit conditions, while at other stages, irrespective of the water supply of the plants, they had a complementary effect $(1<\mathrm{RYT}<2)$. According to Sobkowicz and Podgórska-Lesiak [60], complementarity always occurs at the early plant development stages in the additive pattern. Before competition or other effects of emerging plants occur, RYT in the additive mixture is always equal to 2, since the yield of each species is the same in the mixture as in the single-species sowing. At subsequent stages of development, barley was more competitive against rye-grass. This is a result of the higher initial barley growth rate following the emergence, which determined its competitive advantage over the slower growing catch crop [30]. A species that grows faster makes use of the necessary growth resources and makes them unavailable to other species [30]. In the current study, the strength of species' competition was changing during vegetation. Both under the conditions of the optimal plants' water supply and of water deficit, barley competed more strongly during the tillering and stem elongation stages and this phenomenon, then started to decrease in intensity. 
At the same time, at the barley stem elongation and heading stages, the competition of rye-grass against the cereal $\left(R Y_{B}\right)$ began to intensify, which is probably due to the higher growth rate of rye-grass. Similar observations as regards oats as well as rye-grass and vetch catch crop are presented by Paris et al. [80]

\section{Conclusions}

Water deficit had no effect on the phosphorus content in the above-ground parts of spring barley and Italian rye-grass. This factor reduced phosphorus accumulation in the biomass of barley (the stems, leaves and spikes) and of rye-grass (the stems and leaves) from the emergence to the end of plant growth, both when the plants were cultivated as a single species and in a mixture. Water deficit inhibited the phosphorus accumulation in the barley biomass more than the competition of rye-grass. The competition from barley was, for rye-grass, a stronger factor hindering phosphorus accumulation in the stems and leaves than water deficit. Spring barley was a stronger competitor than rye-grass. Irrespective of the water supply of the plants, the competition intensified until the stem elongation phase. The full competition was noted at the stages of most intense barley development, i.e., during the stem elongation and heading. Underwater deficit inter-species competition for P intensified, which further weakened the P uptake both by barley and rye-grass. This phenomenon should be taken into account when recommending the undersowing of barley with Italian rye-grass for sustainable climate-smart agriculture.

Supplementary Materials: The following are available online at http://www.mdpi.com/2077-0472/10/8/329/s1, Table S1: Phosphorus content of the above-ground biomass of barley ( $\mathrm{g} \mathrm{kg}^{-1}$ dry matter), Table S2: Phosphorus content of the above-ground biomass of rye-grass $\left(\mathrm{g} \mathrm{kg}^{-1}\right.$ dry matter).

Author Contributions: Conceptualization, M.W., M.J. and M.K.K.; methodology, M.W., M.J. and M.K.K.; formal analysis, M.K.K. and M.J.; investigation, M.K.K., M.J., M.W. and K.T.; data curation, M.W. and M.K.K.; writing—original draft preparation, M.K.K.; writing—review and editing, M.J.; visualization, M.K.K. and M.J.; funding acquisition, M.K.K., M.J., M.W. and K.T. All authors have read and agreed to the published version of the manuscript.

Funding: This research was funded by the Ministry of Science and Higher Education of Poland, grant number N N310 082836.

Acknowledgments: The authors kindly acknowledge the technical support of Przemysław Makowski from the University of Warmia and Mazury in Olsztyn.

Conflicts of Interest: The authors declare no conflict of interest.

\section{References}

1. Suzuki, N.; Rivero, R.M.; Shulaev, V.; Blumwald, E.; Mittler, R. Abiotic and biotic stress combinations. New Phytol. 2014, 203, 32-43. [CrossRef] [PubMed]

2. Valliyodan, B.; Nguyen, H.T. Understanding regulatory networks and engineering for enhanced drought tolerance in plants. Curr. Opin. Plant Biol. 2006, 9, 189-195. [CrossRef] [PubMed]

3. Michalak, D. Adapting to climate change and effective water management in Polish agriculture-At the level of government institutions and farms. Ecohydrol. Hydrobiol. 2020, 20, 134-141. [CrossRef]

4. Hänsel, S.; Ustrnul, Z.; Łupikasza, E.; Skalak, P. Assessing seasonal drought variations and trends over Central Europe. Adv. Water Resour. 2019, 127, 53-75. [CrossRef]

5. Szwed, M. Variability of precipitation in Poland under climate change. Theor. Appl. Climatol. 2019, 135, 1003-1015. [CrossRef]

6. da Silva, E.C.; Nogueira, R.; da Silva, M.A.; de Albuquerque, M.B. Drought stress and plant nutrition. Plant Stress 2011, 5, 32-41.

7. Crush, J.R.; Easton, H.S.; Waller, J.E.; Hume, D.E.; Faville, M.J. Genotypic variation in patterns of root distribution, nitrate interception and response to moisture stress of a perennial ryegrass (Lolium perenne L.) mapping population. Grass Forage Sci. 2007, 62, 265-273. [CrossRef]

8. Samarah, N.H.; Alqudah, A.M.; Amayreh, J.A.; McAndrews, G.M. The effect of late-terminal drought stress on yield components of four barley cultivars. J. Agron. Crop Sci. 2009, 195, 427-441. [CrossRef] 
9. Pecio, A.; Wach, D. Grain yield and yield components of spring barley genotypes as the indicators of their tolerance to temporal drought stress. Pol. J. Agron. 2015, 21, 19-27.

10. Cyriac, D.; Hofmann, R.W.; Stewart, A.; Sathish, P.; Winefield, C.S.; Moot, D.J. Intraspecific differences in long-term drought tolerance in perennial ryegrass. PLoS ONE 2018, 13, e194977. [CrossRef]

11. Aronsson, H.; Hansen, E.M.; Thomsen, I.K.; Liu, J.; Øgaard, A.F.; Känkänen, H.; Ulén, B. The ability of cover crops to reduce nitrogen and phosphorus losses from arable land in southern Scandinavia and Finland. J. Soil Water Conserv. 2016, 71, 41-55. [CrossRef]

12. Żuk-Gołaszewska, K.; Wanic, M.; Orzech, K. The role of catch crops in field plant production-A review. J. Elem. 2019, 24, 575-587. [CrossRef]

13. Wanic, M.; Zuk-Golaszewska, K.; Orzech, K. Catch crops and the soil environment-A review of the literature. J. Elem. 2019, 24, 31-45. [CrossRef]

14. Arlauskiene, A.; Maiksteniene, S.; Slepetiene, A. Application of environmental protection measures for clay loam cambisol used for agricultural purposes. J. Environ. Eng. Landsc. Manag. 2011, 19, 71-80. [CrossRef]

15. Doltra, J.; Olesen, J.E. The role of catch crops in the ecological intensification of spring cereals in organic farming under Nordic climate. Eur. J. Agron. 2013, 44, 98-108. [CrossRef]

16. Hansen, E.M.; Eriksen, J.; Vinther, F.P. Catch crop strategy and nitrate leaching following grazed grass-clover. Soil Use Manag. 2007, 23, 348-358. [CrossRef]

17. Känkänen, H.; Eriksson, C. Effects of undersown crops on soil mineral $\mathrm{N}$ and grain yield of spring barley. Eur. J. Agron. 2007, 27, 25-34. [CrossRef]

18. Malcolm, B.J.; Moir, J.L.; Cameron, K.C.; Di, H.J.; Edwards, G.R. Influence of plant growth and root architecture of Italian ryegrass (Lolium multiflorum) and tall fescue (Festuca arundinacea) on $\mathrm{N}$ recovery during winter. Grass Forage Sci. 2015, 70, 600-610. [CrossRef]

19. Abdalla, M.; Hastings, A.; Cheng, K.; Yue, Q.; Chadwick, D.; Espenberg, M.; Truu, J.; Rees, R.M.; Smith, P. A critical review of the impacts of cover crops on nitrogen leaching, net greenhouse gas balance and crop productivity. Glob. Chang. Biol. 2019, 25, 2530-2543. [CrossRef]

20. Guardia, G.; Aguilera, E.; Vallejo, A.; Sanz-Cobena, A.; Alonso-Ayuso, M.; Quemada, M. Effective climate change mitigation through cover cropping and integrated fertilization: A global warming potential assessment from a 10-year field experiment. J. Clean. Prod. 2019, 241. [CrossRef]

21. Bert, S.; Bas, J.; Wiepie, H.; Wil, H.; Luis, A.J.; Jonas, K. Adoption of Cover Crops for Climate Change Mitigation in the EU; Joint Research Centre (Seville Site): Luxembourg, 2019.

22. Sobkowicz, P. Uptake and use of nitrogen in the cultivation of spring barley with undersown Persian clover and serradella. Probl. Inż. Rol. 2009, 2, 99-106.

23. Wanic, M.; Myśliwiec, M.; Orzech, K.; Michalska, M.; Denert, M. Competition for nitrogen, phosphorus, potassium and magnesium between spring wheat and persian clover depending on the density of plants. J. Elem. 2017, 22, 1081-1093. [CrossRef]

24. Jastrzebska, M.; Kostrzewska, M.K.; Wanic, M.; Makowski, P.; Treder, K. Phosphorus content in spring Barley and red clover plants in pure and mixed sowing. Acta Sci. Pol. Agric. 2015, 14, 21-32.

25. Kunelius, H.T.; McRae, K.B.; Dürr, G.H.; Fillmore, S.A.E. Management of Italian and perennial ryegrasses for seed and forage production in crop rotations. J. Agron. Crop Sci. 2004, 190, 130-137. [CrossRef]

26. Salonen, J.; Ketoja, E. Undersown cover crops have limited weed suppression potential when reducing tillage intensity in organically grown cereals. Org. Agric. 2020, 10, 107-121. [CrossRef]

27. Giraldo, P.; Benavente, E.; Manzano-Agugliaro, F.; Gimenez, E. Worldwide research trends on wheat and barley: A bibliometric comparative analysis. Agronomy 2019, 9, 352. [CrossRef]

28. FAO (Food and Agriculture Organization of the United Nations). Crops Barley; 2018. Available online: http://www.fao.org/faostat/en/\#data/QC (accessed on 7 February 2020).

29. Agegnehu, G.; Ghizaw, A.; Sinebo, W. Yield performance and land-use efficiency of barley and faba bean mixed cropping in Ethiopian highlands. Eur. J. Agron. 2006, 25, 202-207. [CrossRef]

30. Sobkowicz, P. Shoot and root competition between spring triticale and field beans during early growth. Acta Sci. Pol. Agric. 2005, 4, 117-126.

31. Wanic, M.; Michalska, M. The influence of competition between spring barley and field pea on content of macroelements in different parts of the plants. Fragm. Agron. 2009, 26, 162-174. 
32. Pappa, V.A.; Rees, R.M.; Walker, R.L.; Baddeley, J.A.; Watson, C.A. Legumes intercropped with spring barley contribute to increased biomass production and carry-over effects. J. Agric. Sci. 2012, 150, 584-594. [CrossRef]

33. Andersen, A.; Olsen, C.C. Rye grass as a catch crop in spring barley. Acta Agric. Scand. Sect. B Soil Plant Sci. 1993, 43, 218-230. [CrossRef]

34. Ohlander, L.; Bergkvist, G.; Stendahl, F.; Kvist, M. Yield of catch crops and spring barley as affected by time of undersowing. Acta Agric. Scand. Sect. B Soil Plant Sci. 1996, 46, 161-168. [CrossRef]

35. Kuraszkiewicz, R.; Palys, E. The influence of cover crops on the yield of aboveground parts of undersown crops. Ann. Univ. Mariae Curie Sklodowska Sectio E Agric. (Poland) 2005, 57, 105-112.

36. Gürel, F.; Öztürk, Z.N.; Uçarlı, C.; Rosellini, D. Barley genes as tools to confer abiotic stress tolerance in crops. Front. Plant Sci. 2016, 7. [CrossRef] [PubMed]

37. Akram, M. Growth and yield components of wheat under water stress of different growth stages. Bangladesh J. Agric. Res. 2011, 36, 455-468. [CrossRef]

38. Ding, J.; Huang, Z.; Zhu, M.; Li, C.; Zhu, X.; Guo, W. Does cyclic water stress damage wheat yield more than a single stress? PLoS ONE 2018, 13, e0195535. [CrossRef]

39. The Biology of Lolium multiflorum Lam (Italian ryegrass), Lolium perenne (perenial ryegrass) and Lolium arundinaceum (Schreb) Darbysh (tall fescue); Department of Primary Industries: Melbourne, VIC, Australia, 2008; p. 83.

40. Varella, A.C.; Carassai, I.J.; Baldissera, T.C.; Nabinger, C.; Lustosa, S.B.C.; Moraes, A.; Teixeira, S.J.; Vargas, A.S.; Radin, B. Annual ryegrass dry matter yield and nitrogen responses to fertiliser $\mathrm{N}$ applications in southern Brazil. Agron. N. Z. 2010, 40, 33-42.

41. Mandić, V.; Simić, A.; Vučković, S.; Stanisavljević, R.; Tomić, Z.; Bijelić, Z.; Krnjaja, V. Management practices effect on seed features of Italian ryegrass following storage period. Biotechnol. Anim. Husb. 2014, 30, 145-152. [CrossRef]

42. Kim, M.; Peng, J.L.; Sung, K. Causality between climatic and soil factors on Italian ryegrass yield in paddy field via climate and soil big data. J. Anim. Sci. Technol. 2019, 61, 324-332. [CrossRef]

43. Olesen, J.E.; Hansen, E.M.; Askegaard, M.; Rasmussen, I.A. The value of catch crops and organic manures for spring barley in organic arable farming. Field Crop. Res. 2007, 100, 168-178. [CrossRef]

44. Płaza, A.; Ceglarek, F.; Gąsiorowska, B.; Królikowska, M.A. The yielding and chemical composition of undersown crops. Fragm. Agron. 2009, 26, 93-99.

45. Schachtman, D.P.; Reid, R.J.; Ayling, S.M. Phosphorus Uptake by Plants: From Soil to Cell. Plant Physiol. 1998, 116, 447-453. [CrossRef] [PubMed]

46. Nawaz, F.; Ahmad, R.; Waraich, E.A.; Naeem, M.S.; Shabbir, R.N. Nutrient uptake, physiological responses, and yield attributes of wheat (triticum aestivum 1.) exposed to early and late drought stress. J. Plant Nutr. 2012, 35, 961-974. [CrossRef]

47. Suriyagoda, L.D.B.; Ryan, M.H.; Renton, M.; Lambers, H. Plant responses to limited moisture and phosphorus availability: A meta-analysis. In Advances in Agronomy; Academic Press Inc.: San Diego, CA, USA, 2014; Volume 124, pp. 143-200.

48. Baligar, V.C.; Fageria, N.K.; He, Z.L. Nutrient use efficiency in plants. Commun. Soil Sci. Plant Anal. 2001, 32, 921-950. [CrossRef]

49. Farahani, S.M.; Chaichi, M.R.; Mazaheri, D.; Afshari, R.T.; Savaghebi, G. Barley grain mineral analysis as affected by different fertilizing systems and by drought stress. J. Agric. Sci. Technol. 2011, 13, 315-326.

50. Gonzalez-Dugo, V.; Durand, J.L.; Gastal, F.; Bariac, T.; Poincheval, J. Restricted root-to-shoot translocation and decreased sink size are responsible for limited nitrogen uptake in three grass species under water deficit. Environ. Exp. Bot. 2012, 75, 258-267. [CrossRef]

51. Brodowska, M.S.; Filipek, T.; Kurzyna-Szklarek, M. Content of magnesium and calcium in cultivated plants depending on various soil supply with nitrogen, potassium, magnesium and sulfur. J. Elem. 2017, 22, 1167-1177. [CrossRef]

52. Bista, D.R.; Heckathorn, S.A.; Jayawardena, D.M.; Mishra, S.; Boldt, J.K. Effects of drought on nutrient uptake and the levels of nutrient-uptake proteins in roots of drought-sensitive and -tolerant grasses. Plants 2018, 7, 28. [CrossRef]

53. Dhima, K.V.; Lithourgidis, A.S.; Vasilakoglou, I.B.; Dordas, C.A. Competition indices of common vetch and cereal intercrops in two seeding ratio. Field Crop. Res. 2007, 100, 249-256. [CrossRef] 
54. Mariotti, M.; Masoni, A.; Ercoli, L.; Arduini, I. Above- and below-ground competition between barley, wheat, lupin and vetch in a cereal and legume intercropping system. Grass Forage Sci. 2009, 64, 401-412. [CrossRef]

55. Eskandari, H.; Ghanbari, A. Effect of different planting pattern of wheat (Triticum aestivum) and bean (Vicia faba) on grain yield, dry matter production and weed biomass. Not. Sci. Biol. 2010, 2, 111-115. [CrossRef]

56. Alaru, M.; Talgre, L.; Luik, A.; Tein, B.; Eremeev, V.; Loit, E. Barley undersown with red clover in organic and conventional systems: Nitrogen aftereffect on legume growth. Zemdirbyste 2017, 104, 131-138. [CrossRef]

57. Darch, T.; Giles, C.D.; Blackwell, M.S.A.; George, T.S.; Brown, L.K.; Menezes-Blackburn, D.; Shand, C.A.; Stutter, M.I.; Lumsdon, D.G.; Mezeli, M.M.; et al. Inter- and intra-species intercropping of barley cultivars and legume species, as affected by soil phosphorus availability. Plant Soil 2018, 427, 125-138. [CrossRef] [PubMed]

58. Weigelt, A.; Jolliffe, P. Indices of plant competition. J. Ecol. 2003, 91, 707-720. [CrossRef]

59. Rahetlah, V.B.; Randrianaivoarivony, J.M.; Andrianarisoa, B.; Razafimpamoa, L.H.; Ramalanjaona, V.L. Yields and quality of Italian ryegrass (Lolium multiflorum) and Common Vetch (Vicia sativa) grown in monocultures and mixed cultures under irrigated conditions in the Highlands of Madagascar. Sustain. Agric. Res. 2013, 2. [CrossRef]

60. Sobkowicz, P.; Podgórska-Lesiak, M. Assessment of barley interactions in mixture with triticale or field pea affected by nitrogen fertilizer rate. Fragm. Agron. 2009, 26, 115-126.

61. Hinsinger, P.; Betencourt, E.; Bernard, L.; Brauman, A.; Plassard, C.; Shen, J.; Tang, X.; Zhang, F. P for two, sharing a scarce resource: Soil phosphorus acquisition in the rhizosphere of intercropped species. Plant Physiol. 2011, 156, 1078-1086. [CrossRef]

62. Li, C.; Dong, Y.; Li, H.; Shen, J.; Zhang, F. Shift from complementarity to facilitation on P uptake by intercropped wheat neighboring with faba bean when available soil P is depleted. Sci. Rep. 2016, 6. [CrossRef]

63. Snaydon, R.W. Replacement or additive designs for competition studies? J. Appl. Ecol. 1991, 28, 930-946. [CrossRef]

64. Semere, T.; Froud-Williams, R.J. The effect of pea cultivar and water stress on root and shoot competition between vegetative plants of maize and pea. J. Appl. Ecol. 2001, 38, 137-145. [CrossRef]

65. Pasze-Oznaczanie Zawartości Fosforu-Metoda Spektrometryczna; Polski Komitet Normalizacyjny: Warszawa, Polska, 2000; p. 9.

66. De Wit, C.T.; Van den Bergh, J.P. Competition between herbage plants. J. Agric. Sci. 1965, 13, $212-221$.

67. Wilson, J.B. Shoot competition and root competition. J. Appl. Ecol. 1988, 25, 279-296. [CrossRef]

68. StatSoft, I. Statistica (Data Analysis Software System), Version 12; Statsoft Inc.: Tulsa, OK, USA, 2014.

69. Kristoffersen, A.Ø.; Riley, H. Effects of soil compaction and moisture regime on the root and shoot growth and phosphorus uptake of barley plants growing on soils with varying phosphorus status. Nutr. Cycl. Agroecosyst. 2005, 72, 135-146. [CrossRef]

70. Alghabari, F.; Ihsan, M.Z. Effects of drought stress on growth, grain filling duration, yield and quality attributes of barley (Hordeum vulgare L.). Bangladesh J. Bot. 2018, 47, 421-428. [CrossRef]

71. Ali, A.H.; Mansorr, H.N. Effect of imposed water stress at certain growth stages on growth and yield of barley grown under different planting patterns. Plant Arch. 2018, 18, 1735-1744.

72. Boudiar, R.; Casas, A.M.; Gioia, T.; Fiorani, F.; Nagel, K.A.; Igartua, E. Effects of low water availability on root placement and shoot development in landraces and modern barley cultivars. Agronomy 2020, 10, 134. [CrossRef]

73. AbdElgawad, H.; Peshev, D.; Zinta, G.; Van Den Ende, W.; Janssens, I.A.; Asard, H. Climate extreme effects on the chemical composition of temperate grassland species under ambient and elevated CO2: A comparison of fructan and non-fructan accumulators. PLoS ONE 2014, 9, e92044. [CrossRef]

74. Høgh-Jensen, H.; Schjoerring, J.K. Interactions between nitrogen, phosphorus and potassium determine growth and N2-fixation in white clover and ryegrass leys. Nutr. Cycl. Agroecosyst. 2010, 87, 327-338. [CrossRef]

75. Brink, G.E.; Pederson, G.A.; Sistani, K.R.; Fairbrother, T.E. Forages: Uptake of selected nutrients by temperate grasses and legumes. Agron. J. 2001, 93, 887-890. [CrossRef]

76. Burkitt, L.L.; Turner, L.R.; Donaghy, D.J.; Fulkerson, W.J.; Smethurst, P.J.; Roche, J.R. Characterisation of phosphorus uptake by perennial ryegrass (Lolium perenne L.) during regrowth. N. Z. J. Agric. Res. 2009, 52, 195-202. [CrossRef] 
77. Norris, I.B.; Thomas, H. Recovery of ryegrass species from drought. J. Agric. Sci. 1982, 98, 623-628. [CrossRef]

78. Jerónimo, P.A.; Hrabě, F.; Knot, P.; Kvasnovský, M. Evaluation of suitability of grass species for dry conditions (water stress). Acta Univ. Agric. Silvic. Mendel. Brun. 2014, 62, 953-960. [CrossRef]

79. Staniak, M. The impact of drought stress on the yields and food value of selected forage grasses. Acta Agrobot. 2016, 69. [CrossRef]

80. Paris, W.; Marchesan, R.; Cecato, U.; Martin, T.N.; Ziech, M.F.; Borges, G.D.S. Dynamics of yield and nutritional value for winter forage intercropping. Acta Sci. Anim. Sci. 2012, 34, 109-115. [CrossRef]

(C) 2020 by the authors. Licensee MDPI, Basel, Switzerland. This article is an open access article distributed under the terms and conditions of the Creative Commons Attribution (CC BY) license (http://creativecommons.org/licenses/by/4.0/). 